\title{
Village Management Accountability; Study in Bincau Muara Village, Martapura District, Banjar District
}

Maidi Armansyah", Andi Tenri Sompa, Taufik Hidayat

Master Program of Government Science, Lambung Mangkurat University, Banjarmasin, Indonesia

DOI: $10.36348 /$ sjef.2020.v04i06.006 $\quad$ | Received: 30.05 .2020 | Accepted: 08.06.2020 | Published: 12.06 .2020

*Corresponding author: Maidi Armansyah

\section{Abstract}

This study focuses attention on the application of the principle of accountability in the management of the Village Fund. The purpose of this study was to determine the accountability of the management of the Village Fund in Bincau Muara Village in the Martapura District, Banjar Regency. The approach used in this study refers to a descriptive approach using a value for money data analysis tool that is by measuring the economic level, efficiency, and effectiveness. Data collection methods used in this study are documentation and verification of documents to related parties. The results showed that the accountability of Village Fund management from 2015 to 2018 in Bincau Muara Village, Martapura District, Banjar District was based on evaluating value for money in economic valuation aspects, namely, in 2016, it was recorded to be very economical while in 2015, 2017 and 2018 it was recorded to be quite economical. Then based on the aspect of efficient assessment the results obtained are that 2016 recorded quite efficient while in 2015-2017 and 2018 recorded very efficient. Furthermore, in the aspect of effectiveness assessment, the results obtained are that in 2015 recorded ineffective which then decreased in 2016 to become ineffective and in 2017 increased to be quite effective which then declined again in 2018 to become less effective. 2017 and 2018 are quite economical.

Keywords: accountability, economical, efficiency, and effectiveness.

\begin{abstract}
Copyright @ 2020: This is an open-access article distributed under the terms of the Creative Commons Attribution license which permits unrestricted use, distribution, and reproduction in any medium for non-commercial use (NonCommercial, or CC-BY-NC) provided the original author and source are credited.
\end{abstract}

\section{Preliminary}

Village and regional development is the government's top priority. The portion of the development budget which initially only struggled in the capital city, will be tried to be more leveled throughout Indonesia, where [1, 2] the village was given autonomy in implementing the village development budget. The granting of Village Funds directly from the APBN to be managed by the village community is a third implementation of Nawacita namely to build Indonesia from the periphery and villages. The allocation of Village Funds is mandated by Law (Law) Number 6 of 2014 concerning Villages and Government Regulation (PP) Number 66 of 2014 concerning Village Funds sourced from the State Budget $[3,4]$.
Following the mandate of Law No. 6 of 2014, all Villages in Indonesia since 2015 received Village Funds sourced from the State Budget, including Villages in the Banjar Regency. Banjar District as the third largest district in South Kalimantan Province with an area of 4,668.50 square $\mathrm{km}$ and a population of 554,443 people in 2015 [5], consisting of 277 villages spread across 20 Districts. Banjar District received village funds in the amount of Rp. 79,899,488,029.91 in 2015 while in 2016 the Banjar District received a disbursement of village funds totaling $\mathrm{Rp}$ $164,329,907,000.00$. From the disbursement of the Village Fund, Martapura Subdistrict consisting of 19 Villages received Village funds amounting to Rp.5,027,210,995.27 in 2015 and Rp. $11,274,066,691.23$ in 2016. 
Table-1: Details of TA Village Funds. 2015 in Martapura District, Banjar Regency

\begin{tabular}{|c|l|r|r|r|c|}
\hline No & \multicolumn{1}{|c|}{ Village } & Ceiling $(\mathbf{R p )}$ & Realization (Rp) & \multicolumn{1}{c|}{ Balance (Rp) } & Percentage \\
\hline 1 & Bincau & $279,109,428.13$ & $223,280,000.00$ & $55,829,428.13$ & 80.00 \\
\hline 2 & Talking Estuary & $266,712,962.26$ & $258,837,000.00$ & $7,875,962.26$ & 97.05 \\
\hline 3 & Scan Alus & $263,162,021.66$ & $201,534,000.00$ & $61,628,021.66$ & 76.58 \\
\hline 4 & Indra Sari & $272,040,337.04$ & $228,229,000.00$ & $43,811,337.04$ & 83.90 \\
\hline 5 & Java Sea & $277,725,837.92$ & $101,210,000.00$ & $176,515,837.92$ & 36.44 \\
\hline 6 & Labuan Tabu & $259,957,803.40$ & $258,840,122.76$ & $1,117,680.64$ & 99.57 \\
\hline 7 & Murung Kenanga & $272,984,068.47$ & $272,984,068.47$ & & - \\
\hline 8 & Western Paskah & $257,697,844.55$ & $206,572,107.44$ & $51,125,737.11$ & 80.00 \\
\hline 9 & Southern airing & $257,006,173.60$ & $162,800,000.00$ & $94,206,173.60$ & 63.34 \\
\hline 10 & Northern Airing & $250,478,547.50$ & $204,382,838.00$ & $46,095,709.50$ & 81.60 \\
\hline 11 & Sipai River & $298,238,696.93$ & $242,725,250.00$ & $55,513,446.93$ & 81.39 \\
\hline 12 & New Pond & $253,592,247.54$ & $202,700,000.00$ & $50,892,247.54$ & 79.93 \\
\hline 13 & Tambir Baru Ilir & $247,784,002.77$ & $244,790,181.00$ & $2,993,821.77$ & 98.79 \\
\hline 14 & Tambak Baru Ulu & $256,064,321.46$ & $174,977,089.99$ & $81,087,231.47$ & 68.33 \\
\hline 15 & Tanjung Rema & $287,185,428.00$ & $224,581,853.00$ & $62,603,575.00$ & 78.20 \\
\hline 16 & Tunggul Irang & $249,495,678.06$ & $248,799,135.62$ & $696,542.44$ & 99.72 \\
\hline 17 & Tunggul Irang Ilir & $264,558,552.04$ & $264,558,552.04$ & & -100.00 \\
\hline 18 & Tunggul Irang Ulu & $256,515,014.41$ & $202,000,000.00$ & $54,515,014.41$ & 78.75 \\
\hline 19 & Armrest & $256,902,029.53$ & $204,000,000.00$ & $52,902,029.53$ & 79.41 \\
\hline & Sub Amount & $5,027,210,995.27$ & $4,127,801,198.32$ & $899,409,796.95$ & \\
\hline
\end{tabular}

Source: processed data from the Community Empowerment and Village Government Agency Banjar Regency

Based on table 1, the villages with the highest percentage of realization/absorption of the Village Fund in 2015 in Martapura District were Tunggul Irang Ilir Village and Murung Kenanga Village, with a realization of $100 \%$. Meanwhile, the village with the lowest realization was Desa Jawa Laut, with the realization of only $36.44 \%$. The 2015 Village Fund Annual Report issued by the Community Empowerment and Village Administration Agency of Banjar District revealed that the Village Fund management problems in 2015 included incomplete and late regulations. stipulations such as Regents Regulations on procurement of goods and services in the Village, management of Village funds that have not been transparent, activities that are not following the APBDes and RKPDes, late physical work, low participation and involvement of village communities in village development, the lack of assistant staff and the low competence of the Village Fund apparatus. However, the report did not cite detailed data as detailed supporting evidence of the 2015 Village Fund management problem statements in Banjar District.

The Village Fund itself is sourced from the State Budget as part of the State Finance, following Law no. 17 of 2003 concerning State Finance adheres to the principle of Accountability which is meant as a principle that determines that each activity and the final results of the activities of state administrators must be accountable to the public or the people as holders of the highest sovereignty of the state following the provisions of the applicable laws and regulations [4, 6]. This article aims to describe the analysis of the accountability of Village Fund management in
Martapura District, Banjar District by taking a case study in Bincau Muara Village, Martapura District, and Banjar Regency.

\section{RESEARCH METHODS}

The approach used in this study refers to a descriptive approach. Descriptive research method. An effort-oriented research model illustrates the relationship between variables or factors that influence the emergence of a social phenomenon which is the object of study [7, 8]. This descriptive study was to explore the meanings, variations, and perceptual understanding that led to the emergence of the phenomenon under study. This study uses a case study design to determine the accountability of village fund management programs by taking a case in Bincau Muara Village, Martapura District, and Banjar District [7].

Data collection methods used in this study is documentation and verification of documents to related parties, especially if the required documents are not available [9]. Data collection is obtained from documents related to Village Fund management such as Strategic Plans (Renstra), Village Budget and Revenues (APBDes), Accountability Reports, and other documents. Village Fund Management will be carried out properly if the management refers to the principle of accountability based on value for money. The analysis technique used in this study adapts to the research objectives and characteristics of the research data, in addition to that the data analysis technique can explain the research problem and answer the research objectives of an appropriate technique is to use a descriptive 
analysis horizontally between types of activities to assess the economic level, the level of operational efficiency and the effectiveness of achieving program activity targets $[10,11]$. The data analysis technique used is to find the average value of each component of the calculation of the value of money, namely economic value, efficiency, and effectiveness with the following formula:

\section{Economic level}

Economic level $=$ $\frac{\text { Realized Input }}{\text { Input Plans }}$

Information:

Realization Input $=$ Financial Performance Budget Expenditures

Input Plans = Entering Financial Performance Budget

Value criteria are:

1) $<90 \%)=$ very economical

2) $90 \%-94.99 \%=$ economical

3) $95 \%-100 \%=$ quite economical

4) $100.01-105 \%=$ less economical

5) $>105 \%=$ uneconomical

2. Efficiency Level

Efficiency $=\frac{\text { Realization Efficiency }}{\text { Plan Efficiency }}$

The Efficient Criteria are:

1) $>80 \%=$ very efficient

2) $70 \%$ to $79 \%=$ efficient
3) $60 \%$ to $69 \%=$ efficient enough

4) $50 \%$ to $59 \%=$ less efficient

5) $<50 \%=$ inefficient

3. Effectiveness level

Effectiveness Level $=$

\section{Information}

Outcome $=$ results obtained to measure an output quality (realization)

Output $=$ results obtained for an output quality (plan)

Effective criteria are:

1) $<90 \%)=$ Not effective

2) $90 \%-94,99 \%=$ Not effective

3) $95 \%-100 \%=$ Quite effective

4) $>100 \%=$ Effective

\section{RESULTS AND DISCUSSION}

Development of Muara Bincau Village Fund

2015 was the first year that village funds were rolled out by the central government and transferred through the District / City Regional Revenue and Expenditure Budget as a concrete implementation of Law Number 6 of 2014 concerning Villages so that villages could finance governance, development, community and community empowerment. Following is the budget and realization of the management of the Bincau Muara Village Fund from 2015 to 2018.

Table-2: Budget Acquisition and Realization of Bincau Muara Village Fund Management Year 2015 - 2018

\begin{tabular}{|c|c|c|r|r|}
\hline No & Year & Ceiling $(\mathbf{R p})$ & Realization $(\mathbf{R p})$ & \multicolumn{1}{c|}{ Balance $(\mathbf{R p})$} \\
\hline 1 & 2015 & $266,712,962.26$ & $258,837,000.00$ & $7,875,962.26$ \\
\hline 2 & 2016 & $595,588,078.71$ & $437,467,678.71$ & $158,120,400.00$ \\
\hline
\end{tabular}

Outcome

The output

\begin{tabular}{|l|l|l|l|l|}
\hline 3 & 2017 & $758,003,692.00$ & $741,230,777.00$ & $16,772,915.00$ \\
\hline 4 & 2018 & $657,094,000.00$ & $636,867,856.00$ & $20,226,344.00$ \\
\hline
\end{tabular}

Source: data processed from the Profile of the Village of Bincau Muara, Banjar Regency 2015-2018

In addition to obtaining a budget and realizing the management of the Bincau Muara
Village Fund, the following is the development of Village Original Revenues from 2015 to 2018.

Table-3: Village Original Income (PAD) in Bincau Muara Village in 2015 - 2018

\begin{tabular}{|l|l|l|}
\hline No & Description & Village Original Income (PAD) \\
\hline $\mathbf{2 0 1 5}$ & $\mathbf{2 , 4 0 0 , 0 0 0 . 0 0}$ \\
\hline 1 & SKT Making Fee & $2,400,000.00$ \\
\hline In $\mathbf{2 0 1 6}$ & $\mathbf{2 4 , 0 0 0 , 0 0 0 . 0 0}$ \\
\hline 1 & Proceeds from leasing land owned by the village & $2,000,000.00$ \\
\hline 2 & Proceeds from tent rentals, village social chairs & $10,000,000.00$ \\
\hline 3 & $\begin{array}{l}\text { Results of mutual assistance and participation } \\
\text { village development }\end{array}$ & $12,000,000.00$ \\
\hline $\mathbf{2 0 1 7}$ & & $\mathbf{6 2 , 9 6 7 , 5 0 0 . 0 0}$ \\
\hline 1 & Ground the village treasury & $1,000,000.00$ \\
\hline 2 & Results asset the other & $10,000,000.00$ \\
\hline 3 & $\begin{array}{l}\text { Results of mutual assistance and participation } \\
\text { village development }\end{array}$ & $51,967,500.00$ \\
\hline
\end{tabular}




\begin{tabular}{|l|l|l|}
\hline $\mathbf{2 0 1 8}$ & $\mathbf{3 5 , 9 1 7 , 7 7 3 . 0 0}$ \\
\hline 1 & Village cash yields & $1,000,000.00$ \\
\hline 2 & Rental yield asset to another village & $6,938,378.00$ \\
\hline 3 & $\begin{array}{l}\text { Results of mutual assistance and participation } \\
\text { village development }\end{array}$ & $27,979,395.00$ \\
\hline
\end{tabular}

Source: data processed from the Profile of the Village of Bincau Muara, Banjar Regency 2015-2018

\section{Use of the 2015 Bincau Muara Village Fund}

The village government of Bincau Muara received village funding in 2015 amounting to $\mathrm{Rp}$. 266,712,962.26, where the funds were budgeted to finance in 2 (two) expenditure groups, namely Village Development Expenditures, Rp. 248,839,765.00 and
Village Community Development Guidance Expenditures in the form of Social Assistance in the amount of Rp. 14,000,000.00 and 1 (one) Funding

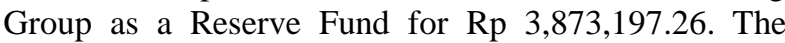
following is a detailed table of the budget and the realization of its use.

Table-4: Budget Expenditures and Realization of Funds Management Muara Bincau Village in 2015

\begin{tabular}{|l|l|l|l|}
\hline No & Description & Budget (Rp) & Realization (Rp) \\
\hline Shopping group & & \\
\hline I & Village Development & $\mathbf{2 4 8 , 8 3 9 , 7 6 5 . 0 0}$ & $\mathbf{2 4 4 , 8 3 7 , 0 0 0 . 0 0}$ \\
\hline 1 & Irrigation Duct Repair & & \\
\hline- & Making the Tabat & $18,875,000.00$ & $18,875,000.00$ \\
\hline 2 & Asphalting Village Roads & & \\
\hline- & Road Procurement & $178,150,000.00$ & $175,000,000.00$ \\
\hline 3 & Maintenance of Buildings, Roads, and Bridges & & \\
\hline- & Road Maintenance & $16,000,000.00$ & $16,000,000.00$ \\
\hline- & Repair of Village Hall Ceiling & $9,964,765.00$ & $9,112,000.00$ \\
\hline 4 & Procurement of Equipment and Machines & & \\
\hline- & Trash Can Procurement & $6,150,000.00$ & $6,150,000.00$ \\
\hline- & Procurement of Post Harvest Equipment & $12,500,000.00$ & $12,500,000.00$ \\
\hline- & Manufacture of garbage bins & $7,200,000.00$ & $7,200,000.00$ \\
\hline II & Village Community Development Guidance Group Expenditures & $\mathbf{1 4 , 0 0 0 , 0 0 0 . 0 0}$ & $\mathbf{1 4 , 0 0 0 , 0 0 0 . 0 0}$ \\
\hline 1 & Social Assistance & & \\
\hline- & Posyandu Operational Assistance & $11,000,000.00$ & $11,000,000.00$ \\
\hline- & PAUD Operational Assistance & $3,000,000.00$ & $3,000,000.00$ \\
\hline III & Reserved fund & $\mathbf{3 , 8 7 3 , 1 9 7 . 2 6}$ & - \\
\hline 1 & Reserve Fund for Pilkades & $3,873,197.26$ & - \\
\hline amount & $\mathbf{2 6 6 , 7 1 2 , 9 6 2 . 2 6}$ & $\mathbf{2 5 8 , 8 3 7 , 0 0 0 . 0 0}$ \\
\hline
\end{tabular}

Source: data processed in 2015 Bincau Muara Village Banjar Village Financial Report

\section{Use of the 2016 Bincau Muara Village Fund}

The village government of Bincau Muara received village funding in 2016, amounting to $\mathrm{Rp}$. $595,588,078.71$ which consists of 2 (two) expenditure groups namely Village Development Expenditures of
Rp. 591,955,078.81and Village Community Development Guidance Group Expenditures in the amount of Rp. 3,545,000.00. The following is a detailed table of the budget and the realization of its use.

Table-5: Budget and Budget Realization of Fund Management Muara Bincau Village in 2016

\begin{tabular}{|c|l|r|r|}
\hline \multicolumn{1}{|c|}{ No Description } & \multicolumn{1}{|c|}{ Budget (Rp) } & \multicolumn{1}{|c|}{ Realization (Rp) } \\
\hline Shopping group & & \\
\hline I & Village Development & $\mathbf{5 9 1 , 9 5 5 , 0 7 8 . 8 1}$ & $\mathbf{4 3 3 , 9 2 2 , 6 7 8 . 7 1}$ \\
\hline 1 & Irrigation Duct Repair & $10,500,000.00$ & $10,500,000.00$ \\
\hline 2 & Building and Building Construction & & \\
\hline- & Development Poskesdes & $129,075,000.00$ & $129,075,000.00$ \\
\hline 3 & Road Procurement & & \\
\hline- & Road construction & $35,000,000.00$ & $35,000,000.00$ \\
\hline 4 & Clean Water Installation Procurement & $5,000,000.00$ & $5,000,000.00$ \\
\hline 5 & Making Village Roads & $158,000,000.00$ & \\
\hline 6 & BOP TPK Supporting development activities & \\
\hline- & Operational Supporting Costs Other development activities & & \\
\hline 7 & Other Facilities and Infrastructure & $10,850,000.00$ & $10,850,000.00$ \\
\hline- & Procurement of Medical Devices & & \\
\hline- & Posyandu Operational Assistance & $6,500,000.00$ & $6,500,000.00$ \\
\hline- & PAUD Operational Assistance & $12,815,000.00$ & $12,815,000.00$ \\
\hline 8 & Bridge Renovations & $3,000,000.00$ & $3,000,000.00$ \\
\hline II & Village Community Development Guidance Group Expenditures & $\mathbf{2 3 , 5 4 5 , 0 0 0 . 0 0}$ & $\mathbf{3 , 5 4 5 , 0 0 0 . 0 0}$ \\
\hline 1 & TPK, PTPKD and Pambakal training & $3,545,000.00$ & $3,545,000.00$ \\
\hline & & $\mathbf{5 9 5 , 5 8 8 , 0 7 8 . 7 1}$ & $\mathbf{5 9 5 , 5 8 8 , 0 7 8 . 7 1}$ \\
\hline
\end{tabular}

Source: data processed in the 2016 Bincau Muara Village Banjar District Financial Report 


\section{Use of Bincau Muara Village Fund for 2017}

The village government of Bincau Muara received village funding in 2017 in the amount of $\mathrm{Rp}$. $758,003,650.00$ which funds are budgeted to finance in 3 (three) expenditure groups namely Village
Development Expenditures of Rp. 701,803,692.00, Village Community Empowerment Expenditures of Rp. 48,200,000.00 and Unexpected Expenditure of Rp. $8,000,000.00$. The following is a detailed table of the budget and the realization of its use.

Table-6: Budget and Budget Realization of Bincau Muara Village Fund Management 2017

\begin{tabular}{|r|l|r|r|}
\hline No & \multicolumn{1}{|c|}{ Description } & Budget (Rp) & \multicolumn{1}{|c|}{$\begin{array}{c}\text { Realization } \\
\text { (Rp) }\end{array}$} \\
\hline Shopping group & & \\
\hline I & Village Development & $\mathbf{7 0 1 , 8 0 3 , 6 9 2 . 0 0}$ & $\mathbf{6 8 5 , 0 3 0 , 7 3 5 . 0 0}$ \\
\hline 1 & Irrigation Duct Repair & $10,500,000.00$ & $10,225,000.00$ \\
\hline 2 & Concrete lift / rebate /Bata Pres/ asphalting Jalan Desa RT 1,2,3 and 5 & $159,329,850.00$ & $154,829,850.00$ \\
\hline 3 & Development Public health center & $53,408,900.00$ & $52,566,910.00$ \\
\hline 4 & Construction of Asset Warehouse and Rice Barns & $55,057,500.00$ & $53,132,875.00$ \\
\hline 5 & Building, Road and Network Maintenance Activities for RT Dike Repair 2 & $22,000,000.00$ & $20,000,000.00$ \\
\hline 6 & TGT Capital Expenditures Procurement of machineries / machinery modern & $126,613,300.00$ & $122,807,500.00$ \\
& agriculture & & \\
\hline 7 & Procurement / Maintenance Public sanitation facilities Clean water & $18,000,000.00$ & $18,000,000.00$ \\
\hline 8 & Making village roads RT 4 and 6 & $130,994,350.00$ & $128,494,350.00$ \\
\hline 9 & Procurement of public sanitation / family toilets (Communal \& Personal) & $45,000,000.00$ & $45,000,000.00$ \\
\hline 10 & BOP TPK Supporting development activities & $21,000,000.00$ & $21,000,000.00$ \\
\hline 11 & Capital expenditure for procurement of medical devices & $6,942,500.00$ & $6,942,000$ \\
\hline 12 & Development / Bridge renovation and connecting road & $11,406,250.00$ & $10,481,250.00$ \\
\hline 13 & Bridge Procurement Capital Expenditures & $41,551,000.00$ & $41,551,000.00$ \\
\hline II & Village Community Empowerment Expenditures & $\mathbf{4 8 , 2 0 0 , 0 0 0 . 0 0}$ & $\mathbf{4 8 , 2 0 0 , 0 0 0 . 0 0}$ \\
\hline 1 & Training for Increasing Village Community Economic Efforts & $18,000,000.00$ & $18,000,000.00$ \\
\hline 2 & TPK, PTPKD and Pambakal training & $3,500,000.00$ & $3,500,000.00$ \\
\hline 3 & Posyandu Operational Assistance & $15,900,000.00$ & $15,900,000.00$ \\
\hline 4 & PAUD Operational Assistance & $6,000,000.00$ & $6,000,000.00$ \\
\hline 5 & Perpusdes Operational Assistance & $4,800,000.00$ & $4,800,000.00$ \\
\hline III & Unexpected Shopping & $\mathbf{8 , 0 0 0 , 0 0 0 . 0 0}$ & $\mathbf{8 , 0 0 0 , 0 0 0 . 0 0}$ \\
\hline 1 & Social Assistance to Community Members & $8,000,000.00$ & $8,000,000.00$ \\
\hline & $\quad$ & $\mathbf{7 5 8 , 0 0 3 , 6 5 0 . 0 0}$ & $\mathbf{7 4 1 , 2 3 0 , 7 3 5 . 0 0}$ \\
\hline
\end{tabular}

Source: data processed in 2017 Bincau Muara Village Banjar District Financial Report

\section{Use of Muara Village Bincau Funds in 2018}

The village government of Bincau Muara received village funding in 2018 of $\mathrm{Rp}$. 657,094,000.00 which funds are budgeted to finance in 2 (two) expenditure groups namely Village Development
Expenditures of Rp. 555,794,737.00 and Village Community Empowerment Expenditures Rp. $101,299,263.00$. Here is a detailed table of the budget and the realization of its use.

Table-7: Budget Expenditures and Realization of Bincau Muara Village Fund Management 2018

\begin{tabular}{|r|l|r|r|}
\hline No & \multicolumn{1}{|c|}{ Description } & \multicolumn{1}{|c|}{ Budget (Rp) } & Realization (Rp) \\
\hline \multicolumn{1}{|c|}{ I } & Village Development & & \\
\hline 1 & Poskesdes Yard Development & $\mathbf{5 5 5 , 7 9 4 , 7 3 7 . 0 0}$ & $\mathbf{5 4 6 , 9 9 9 , 1 0 6 . 0 0}$ \\
\hline 2 & Procurement of equipment / medical equipment Poskesdes & $60,500,000.00$ & $60,500,000.00$ \\
\hline 3 & Cast Jalan Rabat RT 1 & $11,350,000.00$ & $11,350,000.00$ \\
\hline 4 & Improvement of the road opposite RT 2 to 3 siring batu & $34,260,790.00$ & $34,120,516.00$ \\
\hline 5 & Improvement of Cast Road Rebates on the Opposite River RT 4 & $66,086,462.00$ & $21,163,140.00$ \\
\hline 6 & Improvement of RT Concrete Road Rebates & $21,322,278.00$ & $21,163,140.00$ \\
\hline 7 & Pavement Siring batu + urugan pavement road in RT 6 & $119,341,137.00$ & $968,937.00$ \\
\hline 8 & Ulin Jembatan Rehab RT 1 & $22,000,000.00$ & $22,000,000.00$ \\
\hline 9 & Installation of lights Street / PJU RT 2 to RT 1 & $19,450,000.00$ & $19,450,000.00$ \\
\hline 10 & Additional rice thresher machines, tents, chairs and tables & $30,000,000.00$ & $30,000,000.00$ \\
\hline 11 & Addition of Trash Can from RT 1 to RT 5 & $13,500,000.00$ & $11,150,000.00$ \\
\hline 12 & Poor toilet / toilet assistance for poor families & $35,485,000.00$ & $35,485,000.00$ \\
\hline & & & \\
\hline
\end{tabular}




\begin{tabular}{|r|l|r|r|}
\hline II & Village Community Empowerment Expenditures & $101,299,263.00$ & $89,868,750.00$ \\
\hline 1 & Operational Services + Posyandu and Posbindu Cadre Incentives & $21,760,000.00$ & $21,760,000.00$ \\
\hline 2 & $\begin{array}{l}\text { Operational Assistance Incentives for RA Kindergarten } \\
\text { Teachers }\end{array}$ & $10,140,000.00$ & $10,140,000.00$ \\
\hline 3 & Services / Incentives from the Perpusdes Management Officer & $4,800,000.00$ & $2,880,000.00$ \\
\hline 4 & Incentives for midwives' assistants in the village health service & $6,000,000.00$ & $6,000,000.00$ \\
\hline 5 & Rural Community Group Training & $31,000,000.00$ & $25,895,000$ \\
\hline 6 & $\begin{array}{l}\text { Training on TPK, PTPKD, village institutions and instruments } \\
\text { Village financial managers }\end{array}$ & $15,000,000.00$ & $10,595,000.00$ \\
\hline 7 & Rice Seed Assistance Goods \& Poverty Prevention amount & $\mathbf{6 5 7 , 0 9 4 , 0 0 0 . 0 0}$ & $\mathbf{6 3 6 , 8 6 7 , 8 5 6 . 0 0}$ \\
\hline
\end{tabular}

Source: data processed Bincau Muara Village Financial Report Banjar District 2018

\section{Economic Analysis}

Economic analysis is a comparison of inputs with input values expressed in monetary units. Economics is related to the extent to which public sector organizations can minimize the input resources used, namely by avoiding wasteful and unproductive expenditures. The formulation can be calculated as follows:

Economic level $=$

The criteria for value are:

1) $<90 \%)=$ very economical

2) $90 \%-94.99 \%=$ economical

3) $95 \%-100 \%=$ quite economical

\section{Realized Input} Input Plans

4) $100.01-105 \%=$ less economical

5) $>105 \%=$ uneconomical

Comparison of the economic level of Bincau Muara Village Fund management from 2015 to 2018 as the following table:

Table-8: Economical Level of Bincau Muara Village Fund Management Year 2015 - 2018

\begin{tabular}{|c|l|r|r|r|c|}
\hline No & Year & Ceiling (Rp) & \multicolumn{1}{c|}{ Realization (Rp) } & Economic Rate (\%) & Criteria \\
\hline 1 & 2015 & $266,712,962.26$ & $258,837,000.00$ & 97.05 & Economical enough \\
\hline 2 & 2016 & $595,588,078.71$ & $437,467,678.71$ & 73.45 & Very economical \\
\hline 3 & 2017 & $758,003,692.00$ & $741,230,777.00$ & 97.79 & Economical enough \\
\hline 4 & 2018 & $657,094,000.00$ & $636,867,856.00$ & 96.92 & Economical enough \\
\hline
\end{tabular}

Based on table 8 it can be analyzed that based on the economic level of the management of the Bincau Muara Village Fund from 2015-2018 the results show that the management of the Bincau Muara Village Fund in 2016 was recorded to be very economical with a value of $73.45 \%$ while in 2015, 2017 and 2018 it was recorded to be quite economical. Comparison of the economic level of Bincau Muara Village Fund management from 2015 to 2018 per consecutive expenditure group as in the following table:

Table-9: Economic Levels per Fund Management Expenditure Group Muara Bincau Village in 2015

\begin{tabular}{|c|l|r|r|r|c|}
\hline No & \multicolumn{1}{|c|}{ Description } & Budget (Rp) & Realization (Rp) & \multicolumn{1}{c|}{$\begin{array}{c}\text { Economic } \\
\text { Rate (\%) }\end{array}$} & Criteria \\
\hline Shopping group & & & & \\
\hline I & Village Development & $\mathbf{2 4 8 , 8 3 9 , 7 6 5 . 0 0}$ & $\mathbf{2 4 4 , 8 3 7 , 0 0 0 . 0 0}$ & $\mathbf{9 8 . 3 9}$ & Economical enough \\
\hline 1 & Irrigation Duct Repair & & & & \\
\hline- & Making the Tabat & $18,875,000.00$ & $18,875,000.00$ & 100.00 & Economical enough \\
\hline 2 & Asphalting Village Roads & & & & \\
\hline- & Road Procurement & $178,150,000.00$ & $175,000,000.00$ & 98.23 & Economical enough \\
\hline 3 & $\begin{array}{l}\text { Maintenance of Buildings, } \\
\text { Roads, and Bridges }\end{array}$ & & & & \\
\hline- & Road Maintenance & $16,000,000.00$ & $16,000,000.00$ & 100.00 & Economical enough \\
\hline- & $\begin{array}{l}\text { Repair of Village Hall } \\
\text { Ceiling }\end{array}$ & $9,964,765.00$ & $9,112,000.00$ & 91.44 & economical \\
\hline
\end{tabular}




\begin{tabular}{|c|c|c|c|c|c|}
\hline 4 & $\begin{array}{l}\text { Procurement of Equipment } \\
\text { and Machines }\end{array}$ & & & & \\
\hline- & Trash Can Procurement & $6,150,000.00$ & $6,150,000.00$ & 100.00 & Economical enough \\
\hline- & $\begin{array}{l}\text { Procurement of Post } \\
\text { Harvest Equipment }\end{array}$ & $12,500,000.00$ & $12,500,000.00$ & 100.00 & Economical enough \\
\hline- & $\begin{array}{l}\text { Manufacture of garbage } \\
\text { bins }\end{array}$ & $7,200,000.00$ & $7,200,000.00$ & 100.00 & Economical enough \\
\hline II & $\begin{array}{l}\text { Village Community } \\
\text { Development Guidance } \\
\text { Group Expenditures }\end{array}$ & $14,000,000.00$ & $14,000,000.00$ & 100.00 & Economical enough \\
\hline 1 & Social Assistance & & & & \\
\hline- & $\begin{array}{l}\text { Posyandu Operational } \\
\text { Assistance }\end{array}$ & $11,000,000.00$ & $11,000,000.00$ & 100.00 & Economical enough \\
\hline- & $\begin{array}{l}\text { PAUD Operational } \\
\text { Assistance }\end{array}$ & $3,000,000.00$ & $3,000,000.00$ & 100.00 & Economical enough \\
\hline III & Reserved fund & 3,873,197.26 & - & 0 & \\
\hline 1 & Reserve Fund for Pilkades & $3,873,197.26$ & - & 0 & \\
\hline & amount & $266,712,962.26$ & $258,837,000.00$ & 97.05 & Economical enough \\
\hline
\end{tabular}

Based on table 9, the results show that the economic level of Bincau Muara Village Fund management per expenditure group in 2015 is that all activities obtained are quite economic criteria except activities Repair of Village Hall Ceiling recorded economically with a value of $91.44 \%$, then the group financing for reserve funds there is no realization of use.

Table-10: Economic Levels per Bincau Muara Village Fund Management Expenditure Group in 2016

\begin{tabular}{|c|c|c|c|c|c|}
\hline No & Description & Budget (Rp) & $\begin{array}{l}\text { Realization } \\
(\mathbf{R p})\end{array}$ & $\begin{array}{l}\text { Economic } \\
\text { Rate }(\%) \\
\end{array}$ & Criteria \\
\hline \multicolumn{6}{|c|}{ Shopping group } \\
\hline I & Village Development & $591,955,078.81$ & 433,922,678.71 & 73.47 & Very economical \\
\hline 1 & Irrigation Duct Repair & $10,500,000.00$ & $10,500,000.00$ & 100.00 & Economical enough \\
\hline 2 & $\begin{array}{l}\text { Building and Building } \\
\text { Construction }\end{array}$ & & & & \\
\hline- & Development Poskesdes & $129,075,000.00$ & $129,075,000.00$ & 100.00 & Economical enough \\
\hline 3 & Road Procurement & & & & \\
\hline- & Road construction & $35,000,000.00$ & $35,000,000.00$ & 100.00 & Economical enough \\
\hline 4 & $\begin{array}{l}\text { Clean Water Installation } \\
\text { Procurement }\end{array}$ & $5,000,000.00$ & $5,000,000.00$ & 100.00 & Economical enough \\
\hline 5 & Making Village Roads & $158,000,000.00$ & - & 0 & \\
\hline 6 & $\begin{array}{l}\text { BOP TPK Supporting Keg. } \\
\text { Development }\end{array}$ & & & & \\
\hline- & $\begin{array}{l}\text { Operational Supporting Costs } \\
\text { Other development activities }\end{array}$ & $10,850,000.00$ & $10,850,000.00$ & 100.00 & Economical enough \\
\hline 7 & $\begin{array}{l}\text { Other Facilities and } \\
\text { Infrastructure }\end{array}$ & & & & \\
\hline- & $\begin{array}{l}\text { Procurement of Medical } \\
\text { Devices }\end{array}$ & $6,500,000.00$ & $6,500,000.00$ & 100.00 & Economical enough \\
\hline- & $\begin{array}{l}\text { Posyandu Operational } \\
\text { Assistance }\end{array}$ & $12,815,000.00$ & $12,815,000.00$ & 100.00 & Economical enough \\
\hline- & $\begin{array}{l}\text { PAUD Operational } \\
\text { Assistance }\end{array}$ & $3,000,000.00$ & $3,000,000.00$ & 100.00 & Economical enough \\
\hline 8 & Bridge Renovations & $224,760,078.81$ & $224,760,078.81$ & 100.00 & Economical enough \\
\hline II & $\begin{array}{l}\text { Village Community } \\
\text { Development Guidance } \\
\text { Group Expenditures }\end{array}$ & $3,545,000.00$ & $3,545,000.00$ & 100.00 & Economical enough \\
\hline 1 & $\begin{array}{l}\text { TPK, PTPKD and Pambakal } \\
\text { training }\end{array}$ & $3,545,000.00$ & $3,545,000.00$ & 100.00 & Economical enough \\
\hline & amount & $595,588,078.71$ & 437,588,078.71 & 73.47 & Very economical \\
\hline
\end{tabular}


Based on table 10, the results show that the economic level of Bincau Muara Village Fund management per expenditure group in 2017 is that all activities obtained are quite economic criteria (100\%) except for activities Making Village Roads there was no realization of use so that the Village Development expenditure group was noted to be very economical with a presentation of $73.47 \%$.

Table-11: Economic Levels per Fund Management Expenditure Group Bincau Muara Village in 2017

\begin{tabular}{|c|c|c|c|c|c|}
\hline No & Description & Budget (Rp) & $\begin{array}{c}\text { Realization } \\
(\mathbf{R p})\end{array}$ & $\begin{array}{l}\text { Economic } \\
\text { Rate }(\%)\end{array}$ & Criteria \\
\hline \multicolumn{6}{|c|}{ Shopping group } \\
\hline I & Village Development & 701,803,692.00 & 685,030,735.00 & 97.61 & Economical enough \\
\hline 1 & Irrigation Duct Repair & $10,500,000.00$ & $10,225,000.00$ & 97.38 & Economical enough \\
\hline 2 & $\begin{array}{l}\text { Concrete lift / rebate /Bata Pres/ } \\
\text { asphalting Jalan Desa RT 1,2,3 and } \\
5\end{array}$ & $159,329,850.00$ & $154,829,850.00$ & 97.18 & Economical enough \\
\hline 3 & Development Puskesdes & $53,408,900.00$ & $52,566,910.00$ & 98.42 & Economical enough \\
\hline 4 & $\begin{array}{l}\text { Construction of Asset Warehouse } \\
\text { and Rice Barns }\end{array}$ & $55,057,500.00$ & $53,132,875.00$ & 96.50 & Economical enough \\
\hline 5 & $\begin{array}{l}\text { Building, Road and Network } \\
\text { Maintenance Activities for RT Dike } \\
\text { Repair } 2\end{array}$ & $22,000,000.00$ & $20,000,000.00$ & 90.91 & Economical enough \\
\hline 6 & $\begin{array}{l}\text { TGT Capital Expenditures } \\
\text { Procurement of machineries / } \\
\text { machinery modern agriculture }\end{array}$ & $126,613,300.00$ & $122,807,500.00$ & 96.99 & Economical enough \\
\hline 7 & $\begin{array}{l}\text { Procurement / Maintenance Public } \\
\text { sanitation facilities Clean water }\end{array}$ & $18,000,000.00$ & $18,000,000.00$ & 100.00 & Economical enough \\
\hline 8 & Making village roads RT 4 and 6 & $130,994,350.00$ & $128,494,350.00$ & 98.09 & Economical enough \\
\hline 9 & $\begin{array}{l}\text { Procurement of public sanitation / } \\
\text { family toilet (Communal \& } \\
\text { Personal) }\end{array}$ & $45,000,000.00$ & $45,000,000.00$ & 100.00 & Economical enough \\
\hline 10 & $\begin{array}{l}\text { BOP TPK Supporting development } \\
\text { activities }\end{array}$ & $21,000,000.00$ & $21,000,000.00$ & 100.00 & Economical enough \\
\hline 11 & $\begin{array}{l}\text { Capital expenditure for procurement } \\
\text { of medical devices }\end{array}$ & $6,942,500.00$ & $6,942,000$ & 99.99 & Economical enough \\
\hline 12 & $\begin{array}{l}\text { Development / Bridge renovation } \\
\text { and connecting road }\end{array}$ & $11,406,250.00$ & $10,481,250.00$ & 91.89 & Economical \\
\hline 13 & $\begin{array}{l}\text { Bridge Procurement Capital } \\
\text { Expenditures }\end{array}$ & $41,551,000.00$ & $41,551,000.00$ & 100.00 & Economical enough \\
\hline II & $\begin{array}{l}\text { Village Community } \\
\text { Empowerment Expenditures }\end{array}$ & $48,200,000.00$ & $48,200,000.00$ & 100.00 & Economical enough \\
\hline 1 & $\begin{array}{l}\text { Training for Increasing Village } \\
\text { Community Economic Efforts }\end{array}$ & $18,000,000.00$ & $18,000,000.00$ & 100.00 & Economical enough \\
\hline 2 & $\begin{array}{l}\text { TPK, PTPKD and Pambakal } \\
\text { training }\end{array}$ & $3,500,000.00$ & $3,500,000.00$ & 100.00 & Economical enough \\
\hline 3 & Posyandu Operational Assistance & $15,900,000.00$ & $15,900,000.00$ & 100.00 & Economical enough \\
\hline 4 & PAUD Operational Assistance & $6,000,000.00$ & $6,000,000.00$ & 100.00 & Economical enough \\
\hline 5 & Perpusdes Operational Assistance & $4,800,000.00$ & $4,800,000.00$ & 100.00 & Economical enough \\
\hline III & Unexpected Shopping & $8,000,000.00$ & $8,000,000.00$ & 100.00 & Economical enough \\
\hline 1 & $\begin{array}{l}\text { Social Assistance to Community } \\
\text { Members }\end{array}$ & $8,000,000.00$ & $8,000,000.00$ & 100.00 & Economical enough \\
\hline & amount & $758,003,650.00$ & 741,230,735.00 & 97.79 & Economical enough \\
\hline
\end{tabular}

Based on table 11, the results show that the economic level of the management of the Bincau Muara Village Fund per expenditure group in 2017 is that all activities obtained are quite economic criteria except for the construction and renovation of bridges and connecting roads. Recorded economical with a value of $91.89 \%$. 
Table-12: Economic Levels per Fund Management Expenditure Group Muara Bincau Village in 2018

\begin{tabular}{|c|c|c|c|c|c|}
\hline No & Description & Budget (Rp) & Realization (Rp) & $\begin{array}{c}\text { Economic } \\
\text { Rate }(\%)\end{array}$ & Criteria \\
\hline \multicolumn{6}{|c|}{ Shopping group } \\
\hline $\mathbf{I}$ & Village Development & $555,794,737.00$ & $546,999,106.00$ & 98.42 & Economical enough \\
\hline 1 & Poskesdes Yard Development & $60,500,000.00$ & $60,500,000.00$ & 100.00 & Economical enough \\
\hline 2 & $\begin{array}{l}\text { Procurement of equipment / medical } \\
\text { equipment Poskesdes }\end{array}$ & $11,350,000.00$ & $11,350,000.00$ & 100.00 & Economical enough \\
\hline 3 & Cast Jalan Rabat RT 1 & $34,260,790.00$ & $34,120,516.00$ & 99.59 & Economical enough \\
\hline 4 & $\begin{array}{l}\text { Improvement of the road opposite } \\
\text { RT } 2 \text { to } 3 \text { siring Batu }\end{array}$ & $122,499,070.00$ & $117,465,550.00$ & 95.89 & Economical enough \\
\hline 5 & $\begin{array}{l}\text { Improvement of Cast Road Rebates } \\
\text { on the Opposite River RT } 4\end{array}$ & $66,086,462.00$ & $21,163,140.00$ & 99.78 & Economical enough \\
\hline 6 & $\begin{array}{l}\text { Improvement of RT Concrete Road } \\
\text { Rebates }\end{array}$ & $21,322,278.00$ & $65,942,700.00$ & 99.25 & Economical enough \\
\hline 7 & $\begin{array}{l}\text { Pavement Siring Batu + Pavement } \\
\text { road in RT } 6\end{array}$ & $119,341,137.00$ & $118,372,200.00$ & 99.19 & Economical enough \\
\hline 8 & Ulin Jembatan Rehab RT 1 & $22,000,000.00$ & $22,000,000.00$ & 100.00 & Economical enough \\
\hline 9 & $\begin{array}{l}\text { Installation of lights Street / PJU } \\
\text { RT } 2 \text { to RT } 1\end{array}$ & $19,450,000.00$ & $19,450,000.00$ & 100.00 & Economical enough \\
\hline 10 & $\begin{array}{l}\text { Additional rice thresher machines, } \\
\text { tents, chairs, and tables }\end{array}$ & $30,000,000.00$ & $30,000,000.00$ & 100.00 & Economical enough \\
\hline 11 & $\begin{array}{l}\text { Addition of Trash Can from RT } 1 \text { to } \\
\text { RT } 5\end{array}$ & $13,500,000.00$ & $11,150,000.00$ & 82.59 & very economical \\
\hline 12 & $\begin{array}{l}\text { Poor toilet/toilet assistance for poor } \\
\text { families }\end{array}$ & $35,485,000.00$ & $35,485,000.00$ & 100.00 & Economical \\
\hline II & $\begin{array}{l}\text { Village Community } \\
\text { Empowerment Expenditures }\end{array}$ & $101,299,263.00$ & $89,868,750.00$ & 88.72 & very economical \\
\hline 1 & $\begin{array}{l}\text { Operational Services + Posyandu and } \\
\text { Posbindu Cadre Incentives }\end{array}$ & $21,760,000.00$ & $21,760,000.00$ & 100.00 & Economical enough \\
\hline 2 & $\begin{array}{l}\text { Operational Assistance Incentives } \\
\text { for RA Kindergarten Teachers }\end{array}$ & $10,140,000.00$ & $10,140,000.00$ & 100.00 & Economical enough \\
\hline 3 & $\begin{array}{l}\text { Services / Incentives from the } \\
\text { Perpusdes Management Officer }\end{array}$ & $4,800,000.00$ & $2,880,000.00$ & 60.00 & very economical \\
\hline 4 & $\begin{array}{l}\text { Incentives for midwives' assistants in } \\
\text { the village health service }\end{array}$ & $6,000,000.00$ & $6,000,000.00$ & 100.00 & Economical enough \\
\hline 5 & Rural Community Group Training & $31,000,000.00$ & $25,895,000$ & 83.53 & very economical \\
\hline 6 & $\begin{array}{l}\text { Training on TPK, PTPKD, village } \\
\text { institutions, and instruments Village } \\
\text { financial managers }\end{array}$ & $15,000,000.00$ & $10,595,000.00$ & 70.63 & very economical \\
\hline 7 & $\begin{array}{l}\text { Rice Seed Assistance Goods \& } \\
\text { Poverty Prevention }\end{array}$ & $12,599,263.00$ & $12,598,750.00$ & 100.00 & Economical enough \\
\hline & amount & $657,094,000.00$ & 636,867,856.00 & 96.92 & Economical enough \\
\hline
\end{tabular}

Based on table 12, the results show that the economic level of Bincau Muara Village Fund management per expenditure group in 2018, with details, namely on Village Development expenditure 11 (eleven) activities recorded with sufficient economic criteria and 1 (one) activity, namely activities addition of Trash Can from RT 1 to RT 5 recorded very economical with a value of $82.59 \%$. Furthermore, for Village Community Empowerment spending 4 (four) activities were recorded to be quite economical and 3 (three) activities were recorded to be very economical namely activities/incentives of the Perpusdes Management officer (60\%), Training of Rural Community Groups (83.53\%) and TPK Training, PTPKD, village institutions, and instruments Village financial managers $(70.63 \%)$.

\section{Analysis Efficiency}

Efficiency analysis is a comparison of outputs or inputs that are associated with performance standards or targets that have been set. The formulation can be calculated as follows: 
Level of Efficiency =

The Efficient Criteria are:

1) $>80 \%=$ very efficient

2) $70 \%$ to $79 \%=$ efficient

3) $60 \%$ to $69 \%=$ efficient enough

4) $50 \%$ to $59 \%=$ less efficient

5) $<50 \%=$ inefficient

\section{Realization Efficiency}

Plan Efficiency

Comparison of the efficiency levels of the management of the Bincau Muara Village Fund from 2015 to 2018 as the following table:

Table-13: Level Efficiency Bincau Muara Village Fund Management The year 2015 - 2018

\begin{tabular}{|c|c|r|r|c|r|c|}
\hline \multirow{2}{*}{ No } & \multirow{2}{*}{ Year } & \multirow{2}{*}{$\begin{array}{c}\text { Budget } \\
\text { Realization (Rp) }\end{array}$} & \multicolumn{2}{|c|}{ Number of Activities } & \multirow{2}{*}{$\begin{array}{c}\text { Level } \\
\text { Efficiency (\%) }\end{array}$} & \multirow{2}{*}{ Criteria } \\
\cline { 5 - 6 } & & $258,837,000.00$ & 13 & 12 & 89.58 & Very efficient \\
\hline 1 & 2015 & $437,467,678.71$ & 11 & 10 & 66.77 & Enough efficient \\
\hline 2 & 2016 & $741,230,777.00$ & 19 & 19 & 97.78 & Very efficient \\
\hline 3 & 2017 & $636,867,856.00$ & 19 & 19 & 96.92 & Very efficient \\
\hline 4 & 2018 & &
\end{tabular}

Based on table 13 it can be analyzed that based on the efficiency level of the management of the Bincau Muara Village Fund from 2015-2018 the results show that the management of the Bincau Muara Village Fund in 2016 was recorded to be quite efficient with a value of $66.77 \%$ while in 2015,2017 and 2018 it was recorded to be very efficient.

\section{Effectiveness Analysis}

Analysis of effectiveness is the level of achievement of program results with targets set. Simply put, effectiveness is the comparison of outcomes with the output level of achievement of program results with the targets set. In simple effectiveness is a comparison of outcomes with outputs and the formulation can be calculated as follows:

Effectiveness Level $=$

\section{Outcome}

\section{The output}

\section{Information:}

Outcome $=$ results obtained to measure an output quality (realization of the village budget)

Output $=$ results obtained for a quality of output (village budget plans / targets)

Effective criteria are:

1) $<90 \%)=$ Not effective

2) $90 \%-94,99 \%=$ Not effective

3) $95 \%-100 \%=$ Quite effective

4) $>100 \%=$ Effective

Table-14: Effectiveness of Bincau Muara Village Fund Management Year 2015 - 2018

\begin{tabular}{|c|c|c|c|c|c|c|c|}
\hline \multirow{2}{*}{ No } & \multirow{2}{*}{ Year } & \multirow{2}{*}{ Ceiling (Rp) } & \multirow{2}{*}{$\begin{array}{c}\text { Budget } \\
\text { Realization } \\
(\mathbf{R p}) \\
\end{array}$} & \multicolumn{2}{|c|}{ Number of Activities } & \multirow{2}{*}{$\begin{array}{c}\text { Effectiveness } \\
(\%)\end{array}$} & \multirow{2}{*}{ Criteria } \\
\hline & & & & Plan & Realization & & \\
\hline 1 & 2015 & $266,712,962.26$ & $258,837,000.00$ & 13 & $\begin{array}{r}12(100 \%) \\
1(0 \%)\end{array}$ & 90.00 & Less effective \\
\hline 2 & 2016 & $595,588,078.71$ & $437,467,678.71$ & 11 & $\begin{array}{r}10(100 \%) \\
1(0 \%)\end{array}$ & 89.09 & Ineffective \\
\hline 3 & 2017 & $758,003,692.00$ & $741,230,777.00$ & 19 & $19(100 \%)$ & 97.36 & Effective enough \\
\hline 4 & 2018 & $657,094,000.00$ & $636,867,856.00$ & 19 & $\begin{array}{r}17(100 \%) \\
1(60 \%) \\
1(71 \%) \\
\end{array}$ & 94.74 & Less effective \\
\hline
\end{tabular}

Based on table 14, it can be analyzed that based on the effectiveness of the management of the Bincau Muara Village Fund from 2015-2018 the results show that the management of the Bincau Muara Village Fund that in 2015 was recorded to be less effective which then declined in 2016 to become ineffective 
because 1 (one) activity was not implemented, then in 2017 has increased to be quite effective which then decreased again in 2018 to be less effective. After being analyzed, the activities which cause a decrease in the effectiveness value are in the Shopping group other than Village Development Expenditures, due to the low participation of the village community and the expected results are still not satisfactory.

\section{CONCLUSION}

Accountability of Village Fund management in Bincau Muara Village Martapura Subdistrict Martapura is based on the evaluation of value for money in the aspect of economic valuation based on a comparison between the Village Fund budget data and the realization of its use from 2015 to 2018 namely in 2016 recorded very economically with a value of $73.45 \%$ while in 2015 amounting to $97.05 \%$, in 2017 amounting to $97.79 \%$ and in 2018 amounting to $96.92 \%$ recorded quite economical. Accountability of Village Fund management in Bincau Muara Village Martapura Subdistrict Martapura based on the evaluation of value for money in the aspect of efficient assessment from 2015 to 2018 results show that the management of the Bincau Muara Village Fund in 2016 was recorded to be quite efficient with a value of $66.77 \%$ while in 2015 amounted to $89.58 \%, 2017$ of $97.98 \%$ and in 2018 amounting to $96.92 \%$ was recorded as very efficient. Accountability of Village Fund management in Bincau Muara Village, Martapura Subdistrict Martapura based on evaluation of value for money in the aspect of effectiveness assessment, from 2015 to 2018, it was found that the management of the Bincau Muara Village Fund that in 2015 was $90 \%$ recorded less effective which then decreased in $201689.09 \%$ became ineffective because 1 (one) activity was not carried out, then in $201797.36 \%$ experienced an increase to be quite effective which then declined again in 2018 by $94.74 \%$ to become less effective.

\section{REFFERENCE}

1. Abdul, C. D. (2015). Pelayanan Publik Tingkat Desa. Yogyakarta: INTERPENA.

2. Santoso, P. (2003). Pembaharuan Desa Secara Partisipatif. Yogyakarta: Pustaka Pelajar.

3. Arif, M. (2007). Tata Cara Pengelolaan Keuangan Desa Dan. Pengelolaan Kekayaan Desa. Pekanbaru: ReD Post Press.

4. Ismail, M., Widagdo, A. K., \& Widodo, A. (2016). Sistem Akuntansi Pengelolaan Dana Desa. Jurnal Ekonomi dan Bisnis.

5. Sarman, M. (2004). Panduan Prosedur Penelitian dan Penulisan Tesis. Banjarbaru. Kalsel: Program MSAP UNLAMS.

6. Tanjung, A. H. (2000). Akuntansi, Transparansi, dan Akuntabilitas Keuangan Publik. Yogyakarta: BPFE UGM.

7. Sarman, M. (2004). Pengantar Metodologi Penelitian Sosial. Banjarmasin. Kalsel: Pustaka FISIP UNLAM.

8. Mohammad. (2008). Metode Penelitian Kuantitatif-Kualitatif. Malang: UIN.

9. Moleong, L. J. (2002). Metode Penelitian Kualitatif. Bandung: PT Remaja Rosdakarya.

10. Sugiyono. (2016). Memahami Penelitian Kualitatif. Bandung: Alfabeta.

11. Iskandar. (2008). Metodologi Penelitian Pendidikan dan Sosial (Kuantitatif dan. Kualitatif). Jakarta: GP Press. 